\title{
FUNKCJONOWANIE DOMINIKAŃSKIEGO FOLWARKU W UZINIE KOŁO JEZUPOLA NA PRZEŁOMIE XIX I XX W. W ŚWIETLE ZACHOWANYCH DOKUMENTÓW ZE ZBIORÓW ARCHIWUM POLSKIEJ PROWINCJI DOMINIKANÓW
}

\author{
Abstract \\ The FUNCTIONING OF THE DoMiniCan farm IN UZIN NEAR YeZUPIL aT THE TURN \\ OF THE 19TH AND 20TH CENTURIES IN THE LIGHT OF PRESERVED DOCUMENTS \\ from the Archives of the Polish Dominican Province
}

\begin{abstract}
One of the conditions for the maintenance of monasteries in the past centuries, especially on the eastern borders of the Republic of Poland, was the possession of land and a well-functioning farm. The income from the farm was used by the monks to maintain the monastery buildings. That was the case of Yezupil (Jezupol), now in Ukraine, where not only the Dominican convent was located but a local farm as well. It was situated a few kilometers from the monastery - in the village of Uzin. This article describes its history and functioning at the turn of the 19th and 20th centuries. Information on the farm in Uzin was compiled on the basis of documents preserved in the Archives of the Polish Dominican Province in Kraków.
\end{abstract}

Keywords: Dominicans, farm, Uzin, Yezupil (Jezupol), Dominican monastery

Słowa kluczowe: dominikanie, folwark, Uzin, Jezupol, gospodarstwo

Jednym z podstawowych źródeł funkcjonowania większości klasztorów w dawnych wiekach było posiadanie ziemi, folwarku lub lasu oraz dobrze prosperującego gospodarstwa (zwanego niejednokrotnie w źródłach gumnem). Wszystkie tego typu własności miały przynosić dochody i stanowić utrzymanie ośrodków klasztornych: kościołów, zabudowań, ale i samych zakonników asygnowanych do danych konwentów. Dominikanie owo prawo posiadania nadań ziemskich z przeznaczeniem pokrycia wydatków dotyczących budowania i utrzymania kościołów oraz 
własnych konwentów otrzymali już w XIV w. ${ }^{1}$ Był to przywilej papieski, z którego zakonnicy chętnie korzystali, nie mając niejako innego wyjścia. Wprawdzie od początku swego istnienia przyjęli mendykancki odmienny charakter działalności, jednakże z biegiem lat zaczęli od tego modelu odchodzić, liberalizując swoje własne prawo. Od 1475 r. pełne ubóstwo we wszystkich zakonach żebraczych, nie tylko dominikańskich, zniósł papież Sykstus IV, ustanawiając w zamian prawo posiadania dóbr ziemskich ${ }^{2}$. Dlatego też przy wielu konwentach funkcjonowały folwarki i gospodarstwa. Dziś świadectwem ich istnienia, a niejednokrotnie jedyną pozostałością, są zachowane inwentarze lub inne dokumenty ukazujące model gospodarowania i dochody, jakie dane gumno przynosiło. Zwłaszcza te pierwsze doczekały się edycji i opracowań. Wspomnieć należy chociażby prace historyków, m.in.: Grzegorza Wierzchowskiego ${ }^{3}$, Marka Miławickiego ${ }^{4}$, Tadeusz Trajdosa ${ }^{5}$, Macieja Zdanka ${ }^{6}$.

Niniejszy artykuł traktuje o funkcjonowaniu jednego z takich dominikańskich folwarków, przynależnego do klasztoru pw. Wniebowzięcia Najświętszej Maryi Panny w Jezupolu, gospodarstwa w Uzinie. Tamtejszy konwent dominikanów nigdy nie miał tak ogromnego znaczenia, jak np. Lwów czy Kraków (największe klasztory, najliczniej obsadzone, stanowiące przez lata główną siedzibę prowincji oraz studium dla braci itp.), jednakże posiadał całkiem dobrze prosperujący majątek ziemski, który był w stanie utrzymać nie tylko kilku asygnowanych do Jezupola ojców i ich dzieła budowy i utrzymania zabudowań, w tym kościoła, ale też w późniejszym okresie ochronkę dla dzieci prowadzoną przez siostry zakonne czy pokrywać kontrybucje odprowadzane do kasy prowincji przez wszystkie klasztory. Do Jezupola wysyłani byli także podupadli na zdrowiu ojcowie i bracia. Nie tylko czerpali z dobroczynności tamtejszego powietrza, ale też w pełni korzystali z dobrodziejstw klasztornych, np. z wyżywienia. A to klasztor posiadał własne

${ }^{1}$ G. Wierzchowski, Inwentarz folwarku Piaski z 1755 r. Przyczynek do dziejów gospodarczych sieradzkich dominikanów w XVIII w., [w:] Dominikanie na ziemiach polskich w epoce nowożytnej, red. A. Markiewicz, M. Miławicki, Kraków 2009, s. 469-470; W. Hinnebusch, Dominikanie - krótki zarys dziejów, [w:] Dominikanie. Szkice z dziejów zakonu, red. M. Babraj, Poznań 1986, s. 162; T. Trajdos, Uposażenie klasztoru dominikanów lwowskich w średniowieczu, „Nasza Przeszłość”, 91 (1999), s. 49.

${ }^{2}$ Zob. T. Trajdos, U zarania karmelitów w Polsce, Warszawa 1993, s. 81.

${ }^{3} \mathrm{G}$. Wierzchowski, op. cit., passim.

${ }^{4}$ M. Miławicki, Zaplecze gospodarcze klasztorów dominikańskich $w$ diecezji kamienieckiej w świetle akt wizytacji z 1823 r., [w:] Dominikanie na ziemiach polskich, s. 485-517; idem, Źródła do poznania zaplecza gospodarczego dominikańskiego klasztoru Bożego Ciała we Lwowie w latach 1918-1939, [w:] Історія релігій в Україні. Науковий щорічник, Львів 2006, s. 396-407; idem, Ksztaltowanie się własności ziemskiej klasztoru dominikanów w Krakowie w okresie przedrozbiorowym, [w:] Inter oeconomiam coelestem et terrenam. Mendykanci a zagadnienia ekonomiczne, red. W. Długokęcki, T. Gałuszka, R. Kubicki, A. Zajchowska, Kraków 2011, s. 277-302.

${ }^{5}$ T. Trajdos, op. cit., passim.

${ }^{6} \mathrm{M}$. Zdanek, Dochody dominikanów krakowskich w 1 pot. XVI w., [w:] Inter oeconomiam coelestem et terrenam. Mendykanci a zagadnienia ekonomiczne, red. W. Długokęcki, T. Gałuszka, R. Kubicki, A. Zajchowska, Kraków 2011, s. 259-276. 
(hodowano zwierzęta, z których pozyskiwano mięso, mleko, jaja, uprawiono warzywa itp.). A zatem folwark w Uzinie musiał być dobrze zaopatrzony i zarządzany, aby wszystkie te powinności spełnić. Był ponadto miejscem zatrudnienia lokalnej ludności, zwłaszcza po zniesieniu ciężarów pańszczyźnianych. Jego historia oraz działanie zachowały się dość dobrze również w źródłach archiwalnych, zwłaszcza zgromadzonych w Archiwum Polskiej Prowincji Dominikanów w Krakowie. Może nie jest tych źródeł dużo (zob. bibliografia), ale na pewno pokazują one przekrojowo funkcjonowanie, dochody, wydatki, można rzec całą ekonomię dominikańskiego gospodarstwa. Dzięki zachowanym rachunkom możliwe było odtworzenie, przynajmniej w części, siatki kontaktów zarządców folwarku, sprowadzających potrzebne towary i dobra praktycznie z całej Galicji Zachodniej.

O ile pośród tzw. ekonomii klasztornej znaleźć można sporo publikacji, o tyle mniej pojawia się opracowań dotyczących samego Jezupola. Jedynego dokładnego opracowania dokonał Tomasz Zaucha, opisując kościół parafialny. Jego opracowanie w dużej mierze opiera się bezpośrednio na źródłach, autor używa też wielu analogii, np. do Lwowa ${ }^{7}$. Nawet klasztor dominikanów jako instytucja nie doczekał się pełnego opracowania monograficznego. Historyk dominikański, Sadok Barącz OP, jedynie wzmiankował Jezupol w swoim dziele pt. Rys dziejów zakonu kaznodziejskiego w Polsce ${ }^{8} . Z$ innych autorów wskazać można jeszcze: Łucję Wenc, która jedynie wymienia klasztor w Jezupolu9, czy Aleksandra Czułowskiego ${ }^{10}$. O Uzinie za to nikt $\mathrm{z}$ historyków nie pisał. Niniejszy artykuł można więc traktować $\mathrm{w}$ charakterze swoistego przyczynku do dziejów tych dwóch miejscowości (zwłaszcza Uzina) i ich związków z dominikanami. Być może w przyszłości ten temat zostanie podjęty.

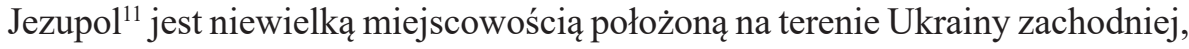
w obwodzie iwanofrankowskim, między rzekami Dniestr i Bystrzyca. Obecnie jest to ok. trzytysięczne miasteczko, które jeszcze w dwudziestoleciu międzywojennym stanowiło siedzibę gminy wiejskiej w powiecie stanisławowskim. Pierwsze wzmianki o Jezupolu pochodzą z I poł. XV w. Wówczas wieś nosiła pogańską

\footnotetext{
${ }^{7}$ T. Zaucha, Kościół parafialny pw. Wniebowzięcia Najświętszej Panny Marii i klasztor oo. Dominikanów w Jezupolu, [w:] Kościoły i klasztory rzymskokatolickie dawnego województwa ruskiego, t. 14, red. M. Podlodowska-Reklewska, Kraków 2006, s. 97-120.

${ }^{8}$ S. Barącz, Rys dziejów zakonu kaznodziejskiego w Polsce, Lwów 1861, t. 2, s. 429-431.

${ }^{9}$ Ł. Wenc, Fundacje i fundatorzy klasztorów dominikańskich i bernardyńskich $w$ Polsce w latach 1580-1648, [w:] Studia nad historia dominikanów w Polsce 1222-1972, red. J. Kłoczowski, t. 1, Warszawa 1975, s. 587-606.

${ }^{10}$ Aleksander Czułowski [Czołowski], Z przeszłości Jezupola i okolicy, Lwów 1890.

${ }^{11}$ Jezupol, [w:] Słownik geograficzny Królestwa Polskiego i innych krajów stowiańskich, wydany pod redakcja Filipa Sulimierskiego, Bronisława Chlebowskiego $i$ Władysława Walewskiego, t. 3, Warszawa 1888, wyd. reprint, Warszawa 1986, s. 581.
} 
nazwę Czeszybiesy. Nazwę obecną i miejski kształt przyjęło w 1597 r. Według legendy uciekający przed Tatarami wojewoda bracławski Jakub Potocki ${ }^{12}$ miał rzucić się do Dniestru i modlić się słowami: Panie Jezusie daj mi pole (czyli drogę), a następnie tylko słowami Jezus... Maria... Uratowawszy się, obiecał założyć na obu brzegach rzeki miasta jako wota dziękczynne. Stąd na prawym brzegu Dniestru znajduje się Jezupol, a na lewym Mariampol. Od 1598 r. Potocki rozpoczął starania o erygowanie parafii w Jezupolu, zapraszając do jej zarządu ojców i braci z Zakonu Braci Kaznodziejów, czyli popularnych dominikanów. Zakończyły się one aktem erekcyjnym z 11 V 1600 r. W myśl innej wersji legendy Potocki miał ratować się z pożaru i nie widząc innego ratunku, zawierzyć się opiece Matki Bożej w cudownym obrazie dominikanów ze Lwowa, obiecując Jej za wybawienie zbudowanie kościoła i klasztoru temu zakonowi ${ }^{13}$. Swoje przyrzeczenie publicznie powtórzył w kościele Dominikanów we Lwowie, już po ustaniu najazdu tatarskiego.

I tak oto w $1600 \mathrm{r}$. stanął na zgliszczach dawnych Czeszybiesów, o której to nazwie już nie pamiętano, klasztor dominikanów w Jezupolu. Jego uposażeniem stała się położona „o milę na zachód (...) [wioska - przyp. aut.] Uzień ze wszystkiemi przynależnościami”"14. Mieszkający w pobliżu, na przedmieściach, mieli oddawać dziesięcinę ze zboża na korzyść klasztoru. Ponadto dominikanie otrzymali „prawo wolnego wrębu w lasy, wolne mleko, rybołówstwo, warzenie wodek i dwadzieścia topek ${ }^{15}$ soli z warzelni Bohorodczańskich" ${ }^{16}$. Uzin ${ }^{17}$ od Jezupola dzieliła odległość $9 \mathrm{~km}$, ale prowadziła tam kamienna droga.

Zarówno Uzin, jak i Jezupol przez cały wiek XVII padały ofiarami najazdów tatarskich, które to doszczętnie grabiły i łupiły klasztor i przynależny mu folwark ${ }^{18}$. Rabowano woły, arendarze zaś uciekali, toteż gospodarstwo nie przynosiło

${ }^{12}$ Potocki Jakub h. Pilawa (ok. 1554-1613) - kasztelan kamieniecki, wojewoda bracławski, generał ziem podolskich, dworzanin Stefana Batorego. Syn Mikołaja i Anny z Czermińskich. Założyciel i pierwszy fundator klasztoru dominikanów w Jezupolu. Zob. A. Lipski, Potocki Jakub h. Pilawa, [w:] Polski Stownik Biograficzny, t. 28, red. E. Rostworowski, Wrocław - Warszawa - Kraków 1984-1984, s. 18-21.

${ }^{13}$ Aleksander Czułowski, op. cit., s. 52. Cyt. za: L. Ulanowski, Wiadomość historyczna o obrazie Matki Boskiej OO. Dominikanów we Lwowie, Lwów 1851, s. 22-23.

${ }^{14}$ Archiwum Polskiej Prowincji Dominikanów w Krakowie (dalej: APPD), sygn. Jz 3 Kronika parafialna i klasztorna oo. Dominikanów w Jezupolu, 1600-1943, s. 3.

${ }^{15}$ Topka - słupek soli w kształcie stożka ze ściętym wierzchołkiem, z dokładnie odmierzoną wagą. Topki uzyskiwano, wlewając do specjalnych dzbanów solankę i podgrzewając ją na ogniu. Woda parowała, a sól osadzała się właśnie w takiej stożkowatej postaci.

${ }^{16}$ APPD, sygn. Jz 3, s. 3.

${ }^{17}$ Uzin, [w:] Stownik geograficzny Królestwa Polskiego i innych krajów słowiańskich, wydany pod redakcja Filipa Sulimierskiego, Bronisława Chlebowskiego i Władysława Walewskiego, t. 12, Warszawa 1892, wyd. reprint, Warszawa 1987, s. 808.

${ }^{18}$ Odnotowano takie najazdy w latach: 1618, 1624-1626, 1649, 1655, 1657, 1672, 1676, 1684 1685 i 1699. Bibliografię dotyczącą najazdów tatarskich zebrał w dużej mierze Ryszard Majewski (R. Majewski, Z problematyki walk z Tatarami w pierwszej połowie XVII wieku, „Sobótka”, 2 (1975), s. 231-241) oraz Dominik Kadzik (D. Kadzik, Obrona ziem ruskich przed najazdami tatarskimi w latach 1575-1578, „Zeszyty Naukowe Uniwersytetu Jagiellońskiego. Prace Historyczne”, 143, z. 2 (2016), s. 269-276). 
dochodów. W 1676 r. hordy tatarskie spaliły zabudowania klasztorne i gospodarskie, bydło i zboże zatracili, a pola leżały odłogiem, gdyż nie było pracowników - uciekli $^{19}$. Względny spokój nastał dopiero w XVIII w.

XIX stulecie nie przyniosło większych szkód ani dla klasztoru, ani dla folwarku. Życie tam toczyło się swoim rytmem. Duże straty były pozostałością po I wojnie światowej - wojska rosyjskie i austro-węgierskie, budując swoje okopy, niszczyły pola oraz wycinały na masową skalę drzewa. Część pozyskanego w ten sposób drewna miała służyć umocnieniu okopów, wycinka zaś powodowana była lepszą widocznością strzelecką. Ponadto dęby, które rosły tam wcześniej, zostały wywiezione do Rosji. Jak zapisano w kronice konwentu w Jezupolu, we wrześniu 1914 r. w Uzinie stacjonowali najpierw żołnierze rosyjscy, później austriaccy. Ci ostatni zabrali z folwarku co lepsze konie, pozostałe zaś oraz bydło zrabowali Moskale. Zniszczyli oni również pasiekę, dewastując 70 barci. Dwa lata później w $1916 \mathrm{r}$. między Uzinem, który był pod zarządem austriackim, a Jezupolem pod zarządem rosyjskim przebiegała linia frontu ${ }^{20}$. Żołnierze, ustępując później z okopów, pozostałe drewno palili. Zmieniła się zatem gospodarka leśna na tym terenie - na pogorzeliskach, na jałowej ziemi zasiały się brzozy. Podobne szkody wyrządzili Ukraińcy w czasie wojny z Polską w latach 1918-1919²1, grabiąc dodatkowo wyposażenie folwarku uzińskiego. Łupem padły narzędzia, inwentarz żywy, zapasy z płodów rolnych oraz urządzenia i sprzęty domowe. Ponadto w ciągu dwóch lat (1918-1920) wykarczowany został tak duży obszar lasu, jaki w normalnych warunkach wystarczyłby na ok. pięcioletnie zaopatrzenie w drzewo.

Folwark dominikański w Uzinie położony był nad trzema potokami: Wołczyńcem, Zdymirem i Smrodnikiem, przy drodze z Jezupola przez Hanusowce do Stanisławowa. Graniczył z gminami Hanusowce, Kołodziejówka, Pobereźce i Olszanica oraz z folwarkiem polnym Płoski. Dominikanie posiadali tam 129 działek, z następującym przeznaczeniem: parcele budowlane (4), ogrodowe (10), ląkowe (39), pastwiska (31), pola orne (17), lasy (26), nieużytki (2). Grunty te położone były blisko siebie, tworząc niejako kształt podkowy. Dłuższe jej ramię stanowiły grunty leśne. Ziemia w Uzinie była średniej jakości:

dominującym typem gleby jest glina z silną domieszką próchnicy, której podglebie stanowi bądź to ił, częściowo nieprzepuszczalny, bądź też w partiach wyżej położonych skała wapienna. Gleba jest na ogół średnio lekka do uprawy, partiami ciężka /przy trakcie/. Grubość warstwy urodzajnej waha się między 0,5 do $2 \mathrm{~m}$; grunta są na ogół suche, potoki wylewają tylko w razie nawałnic (...). Przeważają wystawy i stoki wschodnie, względnie południowe ${ }^{22}$.

${ }^{19}$ APPD, sygn. Jz 17, Plan gospodarczy dla lasów w Uziniu na dziesięciolecie 1932-1941. Egzemplarz dla właściciela lasów. Opracowat inż. Mieczysław Beil, s. 4-5 nlb.

${ }^{20}$ APPD, sygn. Jz. 3, s. 19.

${ }^{21}$ W. Roszkowski, Najnowsza historia Polski 1914-1945, Warszawa 2003, s. 72.

${ }^{22}$ APPD, sygn. Jz 17, [Sprawozdanie o stanie dóbr Uzin z 27 lipca 1933 r.], k. nlb. 
Chociaż słowa te pochodzą z 1933 r., raczej we wcześniejszym okresie funkcjonowania folwarku niewiele było różnic w stanie gleby i nachylenia upraw. Ponadto sprawozdawca podkreślał, iż „gospodarstwo jest prowadzone bez określonego planu i płodozmianu"23. Być może nie stosowano żadnego z systemów uprawy, np. popularnej wówczas trójpolówki - źródła również milczą na ten temat.

Warto w tym miejscu zaznaczyć, jakie były pola działalności folwarku w Uzinie i jak to przekładało się na stan posiadania. Oprócz wspomnianych posiadłości leśnych majątek przynosił dochody z: uprawy zbóż, hodowli inwentarza żywego (bydło, kozy, owce, konie, drób), ale także ze sprzedaży plonów rolnych. Poniższe zestawienia ukazują, jakie rośliny były uprawiane (tabela nr 1) i zwierzęta hodowane (tabela $\mathrm{nr} 2$ ) w folwarku w Uzinie. Co ciekawe, najbardziej pełny jest inwentarz z 1825 r., podający bardzo dokładnie wszystkie dane. W Archiwum Polskiej Prowincji Dominikanów w Krakowie zachowały się tylko cztery inwentarze z Uzina, jednakże są one z lat tak przekrojowych, że pokazują dokładnie hodowlę i uprawę w omawianym okresie. Późniejsze inwentarze nie były już tak dokładnie uzupełniane, nie oznacza to jednak, że zrezygnowano z uprawy pewnych roślin. Z jakiegoś bliżej nieznanego powodu wypisywano tylko ilość zboża. Być może dla sporządzającego spis nie były to rośliny warte poświęcenia uwagi, np. ze względu na swoją przeciętność. Jedno jest pewne, co zaznaczono również w sprawozdaniu z 1933 r.: ,wyczuwa się nastawienie w kierunku produkcji zbożowej / z przewagą pszenicy/ oraz mlecznej" 24 .

Tabela nr 1: Wielkość zbiorów zboża i roślin uprawnych

\begin{tabular}{|c|c|c|c|c|}
\hline Uprawa & $\mathbf{1 8 2 5}$ & $\mathbf{1 9 3 1}$ & $\mathbf{1 9 3 3}$ & $\mathbf{1 9 3 4}$ \\
\hline Żyto ozime & $\begin{array}{c}34 \text { kopy } \\
2 \text { snopy }\end{array}$ & $\begin{array}{c}\text { Rok kop } \\
121 \text { garnców }\end{array}$ & 833 kopy & 175 kop \\
\hline \multirow{2}{*}{ Pszenica ozima } & 40 kop & 1089 kop & 608 kop & 801 ko \\
& $\begin{array}{c}7 \text { korców } 25 \\
16 \text { garnców }\end{array}$ & 345 garnców & & \\
\hline
\end{tabular}

${ }^{23}$ Ibidem.

${ }^{24}$ Ibidem.

${ }^{25}$ Korzec, garniec, kopa i snop były powszechnie używanymi jednostkami miary. Korce i garnce stosowano do podania ilości ziarna, kopy zaś i snopy do ilości zboża ściętego, niemłóconego. Trudno dziś dokładnie określić, ilu kilogramom odpowiadał jeden korzec czy jeden garniec. Wiadomo jedynie, że 32 garnce składały się na 1 korzec. Trzeba również uwzględnić stosowany wówczas system miar, a te były cztery. Zarówno korce, jak i garnce przeliczano na litry. Zob. J. Szymański, Nauki pomocnicze historii, Warszawa 2012, s. 168-172. 


\begin{tabular}{|c|c|c|c|c|}
\hline Pszenica jara & $\begin{array}{c}66 \text { kop } \\
41 \text { snopów } \\
11 \text { korców } \\
14 \text { garnców }\end{array}$ & & 86 kop & 175 kop \\
\hline Jęczmień & $\begin{array}{l}17 \text { korców } \\
16 \text { garnców }\end{array}$ & 115 kop & 162 kopy & 341 kop \\
\hline Orkisz & 50 kop & & & \\
\hline Owies & $\begin{array}{c}70 \text { kop } \\
4 \text { snopy } \\
8 \text { korców } \\
8 \text { garnców }\end{array}$ & $\begin{array}{l}518 \text { kop } \\
35 \text { garnców }\end{array}$ & 793 kopy & 639 kop \\
\hline Proso & $\begin{array}{c}4 \text { korce } \\
21 \text { garnców }\end{array}$ & & & \\
\hline Jagła & $\begin{array}{l}1 \text { korzec } \\
4 \text { garnce }\end{array}$ & & & \\
\hline Hreczka & $\begin{array}{l}68 \text { kop } \\
33 \text { snopy }\end{array}$ & 60 kop & & 19 snopów \\
\hline Kukurydza & 8 kop & 30 garnców & & \\
\hline Ziemniaki & 305 korców & & & \\
\hline Siemienie konopne & $\begin{array}{l}4 \text { korce } \\
8 \text { garnców }\end{array}$ & & & \\
\hline Siemienie poślednie & $\begin{array}{c}1 \text { korzec } \\
8 \text { garnców }\end{array}$ & & & \\
\hline Groch polny & $\begin{array}{c}20 \text { kop } \\
30 \text { snopów }\end{array}$ & & & \\
\hline Groch tyczny & 1 kopa & & & \\
\hline Bób & 1 kopa & & & \\
\hline Fasola & $\begin{array}{c}2 \text { kopy } \\
30 \text { snopów }\end{array}$ & & & \\
\hline
\end{tabular}

Uwagi: Puste pola oznaczają brak danych.

Źródło: opracowanie własne, na podstawie: APPD, sygn. Jz 17 oraz Pp 470. 
Tabela nr 2: Inwentarz żywy

\begin{tabular}{|c|c|c|c|c|c|c|}
\hline $\mathrm{C}_{\text {Hodowla }}$ Rok & $1825^{26}$ & 1931 & 1933 & 1934 & 1936 & 1939 \\
\hline Buhaje & $\begin{array}{l}2 \text { dorosłe, } \\
1 \text { młody }\end{array}$ & 1 & & 1 & & \\
\hline $\begin{array}{l}\text { Woły } \\
\text { robocze }\end{array}$ & 18 & & & & & \\
\hline Byki & 12 & 1 & & & 2 & 1 \\
\hline Krowy & 20 & 31 & 20 & 19 & 24 & 26 \\
\hline Jałówki & 13 & 4 & 1 & 1 & 2 & 9 \\
\hline Cielęta & $\begin{array}{l}9 \text { byczków } \\
9 \text { cieliczek }\end{array}$ & 3 & 12 & 12 & 5 & 3 \\
\hline Kozy & $\begin{array}{c}2 \text { (1cap, } \\
1 \text { koza) }\end{array}$ & & & & & \\
\hline Owce & $\begin{array}{c}55 \\
\text { (16 baranów, } \\
22 \text { owce, } \\
17 \text { jagniąt) }\end{array}$ & & 4 & 4 & & $\begin{array}{c}16 \\
\text { (8 baranów, } \\
8 \text { owiec) }\end{array}$ \\
\hline Konie & $\begin{array}{c}14 \\
\text { (6 klaczy, } \\
3 \text { konie, } \\
3 \text { źrebięta, } \\
2 \text { łoszaki² })\end{array}$ & $\begin{array}{c}20 \\
(17 \text { koni } \\
\text { roboczych, } \\
2 \text { łoszaki, } \\
1 \text { źrebię) }\end{array}$ & 21 & 18 & 18 & $\begin{array}{c}26 \\
\text { (16 koni ro- } \\
\text { boczych, } \\
10 \text { łoszaków) }\end{array}$ \\
\hline $\begin{array}{l}\text { Trzoda } \\
\text { chlewna }\end{array}$ & 58 & 24 & 16 & 22 & 19 & 39 \\
\hline Drób & $\begin{array}{c}77 \\
\text { (7 indyków, } \\
17 \text { gęsi, } \\
13 \text { kaczek, } \\
40 \text { kur) }\end{array}$ & & & & & \\
\hline
\end{tabular}

Uwagi: Puste pola oznaczają brak danych.

Źródło: opracowanie własne, na podstawie: APPD, sygn. Jz 17 oraz Pp 470.

Z form sadzenia zbóż jarych (wczesnych) i ozimych można wywnioskować, iż prace prowadzone były całorocznie. Zboża wykorzystywano zapewne jako surowiec na mąkę do wypieku pieczywa, ale też jako karmę dla zwierząt, zwłaszcza drobiu, czy na wyściółkę dla bydła (słoma). Zboże w ziarnach, po omłocie, stanowiło również

\footnotetext{
${ }^{26} \mathrm{~W}$ inwentarzu z tego roku każde zwierzę rogate zostało rozpisane $\mathrm{z}$ uwagi na gatunek, rasę, wiek, a nawet ubarwienie czy cechy charakterystyczne (np. krowa „Hudzia mała” lub „Siwula mała bez roga"). Na potrzeby niniejszego opracowania liczby te zostały zsumowane, a określenia pominięte.

${ }^{27}$ Łoszak - mały koń, kuc.
} 
środek zapłaty dla zatrudnionych w folwarku chłopów. Pojawiają się również informacje o sprzedaży, ponadto plonami wspierano klasztor dominikanów w Jezupolu, a także ochronkę dla dzieci prowadzoną przez siostry zakonne ${ }^{28}$. Część zboża przeznaczano na siew ozimy. $Z$ hreczki wykonywano zapewne kaszę gryczaną. Hodowano również rośliny tyczne (groch, fasolę, bób), a także ziemniaki i kukurydzę. Skoro $\mathrm{w}$ inwentarzach pojawia się siemię lniane oraz gorszej jakości (poślednie) konopne, uprawiano zapewne konopie i len. Słomę tych roślin poddawano międleniu i uzyskane z niej przędziwo przetwarzano na płótno. A zarówno przędza, jak i sukno pojawiają się w inwentarzu z 1825 r. Sporządzający spis br. Donat Kozicki OP zaznaczył, że część sukna znajdowała się już w foluszu, co by wskazywało nie tylko, że takowy był na terenie gospodarstwa, ale że obrabiano tam również płótno ${ }^{29}$. Folusz jako maszyna służyła do obróbki sukna. Tkaninę z owczej wełny lub lnu spilśniano poprzez wielogodzinne ubijanie (folowanie) specjalnymi młotami (stęporami), napędzanymi wodą z potoku. Tkaninę płukano w zimnej wodzie, następnie ubijano przez dobę. Polewano ją w tym czasie ciepłą i gorącą wodą. Co kilka godzin folowany materiał obracano na drugą stronę. $Z$ ziaren zaś lnu i konopi wyciskano olej. Z przędzy konopnej wykonywano również sznury i liny.

Oprócz produkcji roślinnej w folwarku w Uzinie hodowano zwierzęta. Do pasienia bydła, koni, owiec wykorzystywano okoliczne łąki i pastwiska. Gospodarstwo pod względem tzw. inwentarza żywego nie było małe. Najwięcej było sztuk wszelakiego bydła - zapewne ze względu na właściwości gatunkowe tych zwierząt. Woły robocze można było wykorzystać do prac pociągowych na roli, krowy zaś dawały mleko, a także mięso. Konie zapewne zaprzęgano do wozów, np. przy zwożeniu siana. Równie dużo było owiec, ze względu na mleko, mięso oraz tak cenną wełnę, którą przerabiano na ubrania. Ptactwo hodowano dla mięsa i jaj, gęsi dostarczały ponadto pierza i puchu. Mało dochodowe były kozy, z tego też powodu zapewne nie było ich wiele, a w późniejszych latach zaprzestano w ogóle ich chowu. Sporo było trzody chlewnej, a to za sprawą mięsa, ale także skór, które mogły trafiać do kuśnierzy czy szewców.

Poza uprawą zbóż i hodowlą zwierząt, w folwarku odnaleźć można było także łąki, pastwiska i ogrody. Z pierwszych pozyskiwano siano dobrej jakości, gdyż łąki obfitowały w dobre trawy. Mimo posiadania ogrodów, w których hodowano koniczynę oraz warzywa na własny użytek, nie stwierdzono drzew owocowych, a zatem nie było sadownictwa, które również mogłoby przynosić dochody. Pastwiska zaś przedstawiały minimalną wartość użytkową, a to za sprawą położenia - na szczytach okolicznych wzgórz, przez co trawa na nich była przeważnie wysuszona.

${ }^{28}$ Ochronki dla dzieci były formą wychowania przedszkolnego. Te dobroczynne zakłady powstawały w celu opieki i wychowania ubogich, małych dzieci. Często prowadzone były przez zakony żeńskie. Zaczęły powstawać na początku XIX w. Zob. więcej: A. Bołdyrew, Źródta do badań nad ochronkami jako instytucjami opiekuńczo-wychowawczymi w Królestwie Polskim w XIX i na początku XX wieku, „Studia Paedagogica Ignatiana”, vol. 19, 2006/2, s. 271-289.

${ }^{29}$ APPD, sygn. Jz 17, k. nlb. 
W okresie międzywojennym dużą wagę starano się przywiązywać do gospodarki leśnej, aby odbudować zniszczone działaniami wojennymi lasy, a to za sprawą pozyskiwania i sprzedaży drzewa jako opału i materiału budowlanego. Lasy w folwarku były przeważnie liściaste, z przewagą grabów, dębów, brzóz, wierzby i leszczyny. Jednakże sprawozdanie kontrolne z 1933 r. wykazało spore zaniedbania na tym polu.

Stan gospodarstwa leśnego był dotychczas opłakany. Las odnawiał się sposobem obsiewnym z przypadkowo i niecelowo pozostawionych nasienników i sposobem odroślowym, bez fachowej opieki. (...) Do niedawna dopuszczano pasania bydła w lesie, obecnie pasie tylko służba leśna ${ }^{30}$.

Konwent w Jezupolu dokonywał ciągłych manipulacji ziemią, sprzedając, kupując i zamieniając. I tak np. między 1919 a 1933 r. ilość gruntów leśnych powiększyła się o 2 hektary drogą zamiany z chłopami za działki orne, jednak ogólna ilość posiadanej ziemi zmniejszyła się w tych latach o 20 ha. W 1920 r. sprzedano ponad dziewięć morgów ziemi, z czego dochód miał zasilić odbudowę klasztoru i kościoła po stratach wojennych. Podobnie w latach 1925 i 1927 sprzedano kolejne 18 morgów, celem postawienia ołtarza w kościele w Jezupolu, jednakże środki te zasilić musiały kasę prowincji. Kilka lat później, w 1932 r. sprzedano kolejne 2 morgi, wspierając budowę ochronki dla dzieci w Jezupolu ${ }^{31}$. Dlatego też stan posiadania, a przez to wielkość samego folwarku zmieniała się. I tak w latach 1919-1921 wynosiła 621 ha 57 a $86 \mathrm{~m}^{2}$, by już w 1933 r. wynosić 590 ha 78 a 33 $\mathrm{m}^{2}$, a w 1939 r. 594 ha 36 a $24 \mathrm{~m}^{2}$.

W latach 30 . XX w. zapanował ogólnoświatowy kryzys ${ }^{32}$. Produkcja rolna była mniejsza, spadły ceny artykułów, przez co i dochody folwarku uległy zmniejszeniu. Przeor z Jezupola, gdy tylko mógł, sprzedawał kolejne morgi ziemi. Próbował też zabiegów podniesienia ceny - tak wynika ze skargi wniesionej przez Salomę Gołębiowską w 1934 r. do prowincjała. Pisała ona tak:

Kupiłam u OO. Dominikanów w Uzinie 6 morgów gruntu, płaciłam po 700 zł. Obecnie chciałabym kupić jeszcze parę morgów ziemi w tym samym położeniu, a już Ojciec Przeor żąda ode mnie po 1000 zł od morga. W dzisiejszych czasach to chyba jest niemożliwe, by tak dużo płacić, jeżeli ten pieniądz jest tak drogi ${ }^{33}$.

Zatem kryzys, który dotknął światową gospodarkę, dosięgnął również, a może przede wszystkim, mieszkańców Galicji Zachodniej. Prowincja Polska prawdopodobnie również potrzebowała dodatkowych środków, gdyż pojawiła się w $1934 \mathrm{r}$. propozycja sprzedaży całego majątku w Uzinie Lwowskiemu Kuratorium Szkolnemu, celem założenia szkoły rolniczej. Złożył ją wikariusz prowincjalny o. Henryk

\footnotetext{
${ }^{30}$ Ibidem.

${ }^{31}$ Ibidem.

${ }^{32}$ W. Roszkowski, op. cit., s. 268-276.

${ }^{33}$ APPD, sygn. Pp 470, List Salomei Gotębiowskiej do prowincjała z września 1934 r., k. nlb.
} 
Jakubiec $\mathrm{OP}^{34}$ (w dokumencie niepodpisany), oferując, iż przy zakupie całości gruntów (1027 morgów) cena wyniosłaby 500 zł za morgę, a w przypadku zakupu tylko działek rolnych (350 morgów), 700 zł za morgę ${ }^{35}$. Transakcja jednak nie doszła do skutku, folwark funkcjonował nadal. Borykał się w tym czasie, rzecz jasna, z problemami finansowymi, co podkreślał przy każdej możliwej okazji przeor konwentu w Jezupolu, o. Klemens Kołwa, wymieniając liczne pisma z urzędem prowincjalskim. Przykładowo, w jednym z listów zapisał: „musiałbym wiele wydać pieniędzy. A tych pieniędzy absolutnie nie mam i widoków na nie nie ma, gdyż zbiory są marne" ${ }^{36}$. Do fatalnej sytuacji dochodziły jeszcze klęski żywiołowe: w 1933 r. powódź i zaraza bydlęca (padło 14 sztuk bydła), w 1934 r. susza oraz w 1935 r. klęska mrozów, która spowodowała przemrożenie pszenicy.

Niejako odpowiedzią na kryzys było przekazanie z likwidowanego konwentu w Tyśmienicy inwentarza żywego i martwego na rzecz konwentu w Jezupolu, celem zasilenia folwarku w Uzinie. Zwracał się z tą prośbą o. Klemens do prowincjała, wiedząc, iż dominikanie będą opuszczać Tyśmienicę. Faktycznie nastąpiło to w październiku 1936 r. $^{37}$, a już w listopadzie o. Kołwa przesyłał do prowincjała spis rzeczy przekazanych ${ }^{38}$. Część rzeczy do Uzina trafiła uszkodzonych, co przeor jezupolski złożył na furmanów wiozących towary ${ }^{39}$.

Analizując powyższe dane i wcześniejsze zestawienia tabelaryczne, można postawić tezę o wielkości folwarku w Uzinie. Mimo iż dane nie są kompletne - nie obejmują każdego roku, ale zapisywane były wyrywnie, doskonale widać na ich podstawie, iż gospodarstwo to funkcjonowało całkiem prężnie i było niemałym polem do obrobienia. Dlatego też stosowano system gospodarki pańszczyźnianej, gdzie siłę roboczą stanowili miejscowi chłopi. Ich praca była przymusowa i bezpłatna, co jednak na przestrzeni wieków zmieniło się. Pracownicy otrzymywali zapłaty za swoją pracę, czy to w formie pieniężnej czy w naturze, najczęściej w zbożu. Próba ustalenia dokładnej ilości zatrudnionych nie jest łatwa, gdyż nie był prowadzony dokładny spis - co zresztą zostało wypunktowane jako zarzut: ,administracja nie prowadzi prawidłowych ksiąg gospodarczych"40. Nazwiska chłopów pracujących w folwarku pojawiają się w pojedynczych zapisach. I tak np. w $1933 \mathrm{r}$. folwark zatrudniał 12

${ }^{34}$ Jakubiec Henryk Jan (ur. 1878 r., Raba Wyżna k. Rabki, zm. 1957 r., Wrocław) - dominikanin, jeden z wybitniejszych prowincjałów Polskiej Prowincji, kilkukrotny syndyk konwentów, przeor krakowski, jarosławski i prudnicki oraz wikariusz prowincji. Urząd prowincjała sprawował w latach 1933-1938. Zob. Księga zmartych Braci i Ojców Polskiej Prowincji Zakonu Kaznodziejskiego czyli dominikanów od 2 lipca 1927 roku, czyli od restaurowania Polskiej Prowincji, wyd. IV, Warszawa 2007, s. 110.

${ }^{35}$ APPD, sygn. Pp 470.

${ }^{36}$ APPD, sygn. Pp 470.

${ }^{37}$ P. Krasny, Kościót parafialny p.w. św. Mikołaja i św. Zofii oraz klasztor oo. dominikanów w Tyśmienicy, [w:] Kościoły i klasztory rzymskokatolickie dawnego województwa ruskiego, t. 14, red. M. Podlodowska-Reklewska, Kraków 2006, s. 452.

${ }^{38}$ APPD, sygn. Pp 470, Wykaz rzeczy przywiezionych z Tyśmienicy, k. nlb.

${ }^{39}$ Ibidem.

${ }^{40}$ APPD, sygn. Jz 17, k. nlb.. 
chłopów, za kwoty od 20 zł miesięcznie do 150 zł rocznie oraz odpowiednie daniny w naturze. Nie jest to powiedziane wprost, ale można postawić daleko idący wniosek, iż zarabiający najwięcej mógł być zarządcą folwarku, może przełożonym robotników. Aczkolwiek w „Notatkach o. Jacka Plebańczyka” widnieje zapis, iż „zarządcy za październik [należy się - przyp. aut.] 40 zł" "41. W tych samych notatkach znaleźć można informację, iż gospodyni zarabiała między 30 a 50 zł, a furman 30 . W myśl innego dokumentu z 1933 r. można odtworzyć nazwiska pracowników: gumiennego ${ }^{42}$ Jakuba Jasińskiego, fornali ${ }^{43}$ : Wasyla Bojko, Ołeksa Chudziaka, Semko Bojko, Jurko Dziegciera, Iwana Bojko, pastuchów: Mateusza Borkowskiego i Piotra Korościja, pomocnika pastucha Mikołaja Gawluka, stróża nocnego Rafała Borkowskiego, podleśniczego Franciszka Śliwę, gajowych: Franciszka i Ambrożego Borkowskich ${ }^{44}$.

Uziński folwark podporządkowany był konwentowi w Jezupolu, toteż opiekę nad nim sprawowali ojcowie i bracia asygnowani do tegoż klasztoru. Wszelkie decyzje dotyczące folwarku podejmowane były przez przeorów jezupolskich. Na przełomie XIX i XX w. było ich 11. Pełnili ten urząd następujący ojcowie $^{45}$ : Ambroży Waiss OP $^{46}$ (1860-1862), Nikodem Glass OP ${ }^{47}$ (1875), Jordan Wajtaler OP ${ }^{48}$ (1888-1890), Jakub Patlewicz OP ${ }^{49}$ (1891-1893), Florian Bielat OP $^{50}$ (1894-1903), Tomasz Kosior OP ${ }^{51}$ (1904-1906), Benedykt Prokop OP ${ }^{52}$

\footnotetext{
${ }^{41}$ Ibidem, Notatki o. Jacka Plebańczyka przy składaniu urzędowania na ręcęo. Marka Krasa, k. nlb.

${ }^{42}$ Gumienny - stróż, ekonom w gumnie (gospodarstwie). Zob. https://sjp.pwn.pl/doroszewski/ gumienny;5432153.html [pobrano: 29 III 2021 r.].

${ }^{43}$ Fornal - robotnik folwarczny obsługujący konie. Zwykle na jednego fornala przypadały dwie pary koni. Zob. Słownik języka polskiego, t. 1: A-K, red. M. Szymczak, Warszawa 1978, s. 604.

${ }^{44}$ APPD, sygn. Pp 470, Stużba roczna, k. nlb.

${ }^{45}$ Lata w nawiasach oznaczają występowanie w schematyzmach zakonnych. W dużej mierze pokrywają się z faktycznymi datami sprawowania oficjów.

${ }^{46}$ Waiss Ambroży Wojciech (ur. 1834 r., Klimkówka, zm. 1872 r. Tyśmienica) - dominikanin, przeor konwentów w Jarosławiu, Jezupolu, Tyśmienicy. Kaznodzieja generalny dominikanów, syndyk konwentu we Lwowie, wikariusz parafii. Zob. Kn 73, Kartoteka biograficzna dominikanów polskich, k. nlb.

${ }^{47}$ Glass Nikodem Franciszek Józef (ur. 1813 r., Chomczyn, zm. 1884 r., Podkamień) - dominikanin, prowincjał przez dwie kadencje (1860-1867), nauczyciel w Gimnazjum II we Lwowie, przeor w Bohorodczanach, Jezupolu, Podkamieniu, syndyk we Lwowie, Żółkwi, Jarosławiu, Tyśmienicy i Podkamieniu. Zob. M. Miławicki, Prowincjałowie dominikańskiej Prowincji Galicji i Lodomerii św. Jacka. Prolegomena do badań prozopograficznych, [w:] Historia, ludzie i miejsca. Ksiegga pamiątkowa profesora Henryka Gapskiego, red. R. Kozyrski, Lublin 2019, s. 514.

${ }^{48}$ Wajtaler Jordan (ur. 1820 r., Kraków (?), zm. 1892 r., Dzików (Tarnobrzeg)) - dominikanin, przeor konwentu w Jezupolu, wielokrotny wikariusz parafii dominikańskich, administrator w Chomiakówce. Katecheta i kaznodzieja, infirmarz. Zob. Ibidem, k. nlb.

${ }^{49}$ Patlewicz Jakub (ur. 1846 r., Krosno, zm. 1900 r., Potok Złoty) - dominikanin, krzewiciel różańca świętego, kaznodzieja i misjonarz ludowy. Zob. Księga zmarlych za okres od 1900 do 1972 , oprac. E. Działa, Warszawa 1972, s. 72-73.

${ }^{50}$ Bielat Florian Zygmunt (ur. 1860 r., Przecław, zm. 1934 r., Lwów) - dominikanin, długoletni prowincjał (1903-1911), wielokrotny przełożony klasztorów dominikańskich, gorliwy spowiednik. Zob. ibidem, s. 33.

${ }^{51}$ Kosior Tomasz Michał (ur. 1863 r., Wólka Grodziska, zm. 1918 r., Czortków) - dominikanin, kilkukrotny przeor klasztorów. Zob. ibidem, s. 45.

${ }^{52}$ Prokop Benedykt Jan (ur. 1868 r., Szynwałd, zm. 1928 r., Lwów) - dominikanin, przełożony w Jezupolu, Żółkwi, Bohorodczanach, proboszcz w Krotoszynie. Zob. ibidem, s. 13.
} 
(1907-1919), Jacek Plebańczyk OP ${ }^{53}$ (1919-1928), Marek Kras OP ${ }^{54}$ (1929-1932), Stanisław Hayto OP ${ }^{55}$ (1933), Klemens Kołwa OP ${ }^{56}$ (1934-1942). Był on prawdopodobnie ostatnim przeorem. Schematyzm z 1946 r. wskazuje Jezupol jako domus ordinis derelictae, czyli dom opuszczony. Brak schematyzmów z lat 1942-1946 pozwala podnieść taką tezę, iż to właśnie za przełożeństwa o. Kołwy zniesiono konwent, a wraz z nim zlikwidowano folwark w Uzinie, zapewne przy pomocy rozparcelowania gruntów, jak miało to miejsce w innych majątkach klasztornych na tym terenie (np. w Krotoszynie k. Lwowa ${ }^{57}$ ). Ostatnie dokumenty dotyczące Uzina pochodzą z 1944 r., kronika zaś parafii w Jezupolu kończy się 31 grudnia 1943 r. $^{58}$.

Jednakże to nie przeorzy czy superiorzy konwentu pełnili faktyczny zarząd nad folwarkiem, ale zazwyczaj tzw. bracia konwersi, czyli nieposiadający święceń kapłańskich zakonnicy. W dokumentach archiwalnych pojawiają się następujący bracia $^{59}$ : Szymon Sebastian Janikowski OP ${ }^{60}(1888-1890,1925)$, Mikołaj Hejna OP $^{61}$ (1891-1894), Tadeusz Hrynik OP ${ }^{62}$ (1897-1900), Szymon Gilewicz OP ${ }^{63}$ (1901), Sadok Smoleński OP ${ }^{64}$ (1902-1903), Alwary Korona OP ${ }^{65}$ (1904-1907),

${ }^{53}$ Plebańczyk Jacek Franciszek (ur. 1870 r., Uście Solne k. Bochni, zm. 1940 r., Kraków) - dominikanin, przeor w Tyśmienicy, Jezupolu, proboszcz tamtejszych parafii, przeor w Borku Starym. Zob. Księga zmartych Braci i Ojców Polskiej Prowincji..., s. 117.

${ }^{54}$ Kras Marek Michał (ur. 1890 r., Bryły k. Jasła, zm. 1962 r., Jarosław) - dominikanin, syndyk prowincji, przeor klasztorów w Podkamieniu, Żółkwi, Jezupolu, Tarnobrzegu, Jarosławiu, ceniony kaznodzieja. Zob. ibidem, s. 43.

${ }^{55}$ Hayto Stanisław Edward (ur. 1892 r., Zagacie, zm. 1970 r., Kraków) - dominikanin, magister braci we Lwowie, wikariusz parafii w Jezupolu, przeor w Krakowie, Poznaniu i Wrocławiu, radny prowincji, prowincjalny promotor liturgii. Zob. ibidem, s. 117.

${ }^{56}$ Kołwa Klemens Franciszek (ur. 1887 r., Budziwój, zm. 1950 r., Święta Anna) - dominikanin, kapelan wojskowy, ostatni proboszcz i przeor w Jezupolu, kapelan sióstr dominikanek w Świętej Annie. Zob. ibidem, s. 99.

${ }^{57}$ S. Czyżowicz, M. Czarnecki, Krotoszyn koło Lwowa, Namysłów 2014, s. 161-162.

${ }_{58}$ „Dnia 3 lipca [1944 r. - przyp. aut.] przybył do naszego konwentu [w Jarosławiu - przyp. aut.] o. Klemens Kołwa, przeor jezupolski, po zlikwidowaniu tamtejszego domu, gdyż cała prawie parafia wyjechała z obawy przed rzezią Ukraińców" - zob. APPD, sygn. Js 3, s. 116.

${ }^{59}$ Zob. przyp. 45 (lata w nawiasach).

${ }^{60}$ Janikowski Szymon Sebastian (ur. 1848 r., Ciężkowice k. Chrzanowa, zm. 1929 r., Czortków) - dominikanin, konwers (bez święceń), pracownik klasztorów w Żółkwi, Jezupolu i Czortkowie. Zob. Księga zmartych Braci i Ojców Polskiej Prowincji..., s. 74.

${ }^{61}$ Hejna Mikołaj OP - na obecnym etapie badań postać niezidentyfikowana.

${ }^{62}$ Hrynik Tadeusz (ur. 1833 r., Brzeżany, zm. 1900 r., Jezupol) - dominikanin, konwers, administrator folwarku w Uzinie. Zob. Księga zmartych za okres od 1900 do 1972, s. 73.

${ }^{63}$ Gilewicz Szymon (ur. 1863 r., Paratyn, zm. 1902 r., Lwów) - dominikanin, konwers, administrator folwarku w Uzinie. Zob. ibidem, s. 55.

${ }^{64}$ Smoleński Sadok Wawrzyniec (ur. 1859 r., Ksany k. Pińczowa, zm. 1941 r., Szówsko k. Jarosławia) - dominikanin, konwers, felczer i zielarz, administrator folwarku w Uzinie. Zob. Ksiega zmartych Braci i Ojców Polskiej Prowincji..., s. 83.

${ }^{65}$ Korona Alwary Jan (ur. 1864 r., Stary Sącz, zm. 1942 r., Bohorodoczany) - dominikanin, konwers, pracownik klasztorów w Podkamieniu, Tyśmienicy, Bohorodczanach, Jezupolu, zasłużony gospodarz i zakrystianin. Zob. ibidem, s. 42. 
Anioł Bryja OP ${ }^{66}$ (1909-1919, 1933-1942), Klemens Wierny OP ${ }^{67}$ (1920), Garcjasz Juźwa OP ${ }^{68}$ (1927-1929), Bernard Gerber OP ${ }^{69}$ (1930), Antoni Kowal OP ${ }^{70}$ (19311932). Na szczególną uwagę zasługuje br. Anioł Bryja, dwukrotnie i najdłużej administrujący uzińskim folwarkiem. W dokumentach wymieniany był jako dobry gospodarz, znający się na uprawach i hodowli, co zapewne miało przełożenie na pracę folwarku i przynoszenie przezeń dochodów. Brat Anioł odegrał istotną rolę zwłaszcza w czasie kryzysu - dzięki jego zaradności i umiejętności zarządzenia dochodowość folwarku z roku na rok podnosiła się. Na świecie szalał kryzys, co wydawałoby się, skłaniać powinno do oszczędności. Tymczasem w Uzinie, pod okiem br. Bryi

w roku 1934 poszyto dach na stajnię, poszyto szopę na wozy. W roku 1935 wyprawiono stajnię końską i krowską. W roku 1936 postawiono studnię betonową. Przestawiono piece i kupiono płachtę na młocarkę. Pokryto dom koło kaplicy gontami $(\ldots)^{71}$.

Zatem starano się, aby folwark funkcjonował sprawnie, a potrzebne naprawy, remonty i zakupy były realizowane na bieżąco.

Mając obraz funkcjonowania folwarku, warto zwrócić uwagę na zabudowania, jakie stały w jego obrębie. Istnienie takiego gospodarstwa wymuszało niejako z natury budowę pewnych budynków. W sprawozdaniu z $1933 \mathrm{r}$. wymienione zostały: dom mieszkalny z cegły, kryty blachą, czworak (służący za drewutnię), drewniana szopa na narzędzia, kosznica, kamienna stajnia końska, kamienna obora, stodoła, ceglana chlewnia, ekonomówka, w której funkcjonowała również ochronka prowadzona przez zakonnice, siostry ze Zgromadzenia Franciszkanek Rodziny Maryi, oraz szopa na maszynę kryta strzechą ${ }^{72}$. Informacji o zabudowaniach przynoszą także polisy ubezpieczeniowe z lat 20. i 30. XX w. Pierwszy z zachowanych tego typu dokumentów, spisany w 1923 r., informuje, iż na terenie folwarku stały: drewniana kaplica kryta gontem, murowany, kryty blachą dwór, ekonomówka, stajnia, kurnik, tzw. stelmasznica

\footnotetext{
${ }^{66}$ Bryja Anioł Michał (ur. 1866 Gronków, zm. 1950 Jarosław) - dominikanin, konwers, długoletni administrator folwarku w Uzinie oraz folwarku Lipiny k. Żółkwi. Zob. ibidem, s. 38.

${ }^{67}$ Wierny Klemens Michał (ur. 1874 r., Białka Szlachecka, zm. 1935 r., Czortków) - dominikanin, konwers, pracownik klasztorów w Podkamieniu, Jezupolu, Czortkowie. Pełnił zazwyczaj obowiązku kucharza, zakrystiana i dbał o zaopatrzenie konwentów. Zob. ibidem, s. 16.

${ }^{68}$ Juźwa Garcjasz [Gracjasz] Dominik (ur. 1869 r., Popowce, zm. 1944 r., Podkamień) - dominikanin, konwers, pracownik klasztorów w Jezupolu, Podkamieniu, Czortkowie, męczennik podkamieński. Zob. ibidem, s. 41.

${ }^{69}$ Gerber Bernard Jan (ur. 1911 r., Żelechów Wielki, zm. 1981 r., Jarosław) - dominikanin, konwers, pracownik folwarków przy klasztorach w Żółkwi, Jezupolu, Krakowie, Lublinie, wieloletni zakrystianin, syndyk konwentu w Jarosławiu. Zob. ibidem, s. 106.

${ }^{70}$ Kowal Antoni Andrzej (ur. 1900 r. Poczapińce, zm. 1979 r., Warszawa) - dominikanin, konwers, wychowanek internatu w Żółkwi, zakrystianin i organista w Czortkowie, wychowawca internatów w Lublinie i Jarosławiu. Zob. ibidem, s. 129.

${ }^{71}$ APPD, sygn. Pp 470, Sprawozdanie z przełożeństwa o. Klemensa Kołwy w Jezupolu za okres od 24 listopada 1933 do 24 listopada 1936, k. nlb.

${ }^{72}$ APPD, sygn. Pp 470, Budynki, k. nlb.
} 
stanowiąca mieszkanie stelmacha ${ }^{73}$ oraz spichlerz ${ }^{74}$. Dokument ten dostarcza również rysunku poglądowego, pokazującego układ folwarku. I tak: w centrum gospodarstwa, $10 \mathrm{~m}$ od drogi stał dwór. Po jego prawej stronie znajdowały się kolejno: dom stelmacha, stajnia, kurnik oraz $30 \mathrm{~m}$ dalej - kaplica. Po lewej stronie dworu umiejscowiony był spichlerz oraz nieuwzględniony w wykazie budynek. Ekonomówka stała niemalże równolegle do dworu i drogi. Całość gospodarstwa tworzyła kształt podkowy. Kolejna polisa, z 1937 r. informuje, iż w obrębie folwarku w Uzinie stał dwór, chlewnia, trzy stajnie, stodoła, spichrz (spichlerz), szopa, ekonomówka, komora, dom z gankiem, kaplica i szopa z przybudówką ${ }^{75}$. Rok później pominięta została stodoła, pojawiła się za to wozownia ${ }^{76}$. Być może był to ten sam budynek, zmieniła się prawdopodobnie tylko jego funkcja. Budynki te ubezpieczone były na kwotę 34310 zł, przy składce 59 zł 74 gr (w 1937 r.) oraz 39360 zł w 1938 r., za co dominikanie płacili 53 zł 58 gr.

Ciekawy jest fakt, iż pod koniec funkcjonowania majątku w Uzinie kilka z jego parcel zostało przekazanych pod budowę nowego cmentarza parafialnego. Już w 1937 r. trwały zabiegi w tym kierunku; czynił je proboszcz grekokatolickiej cerkwi w Uzinie, ks. Emiljan Kowalśhyj. Pismem z dnia 23 I 1937 r. do przeora konwentu w Jezupolu zawiadamiał o otrzymaniu z kurii w Stanisławowie polecenia zamknięcia dotychczasowego cmentarza przy cerkwi i urządzenia oraz poświęcenia nowego miejsca grzebalnego. Pisał wówczas:

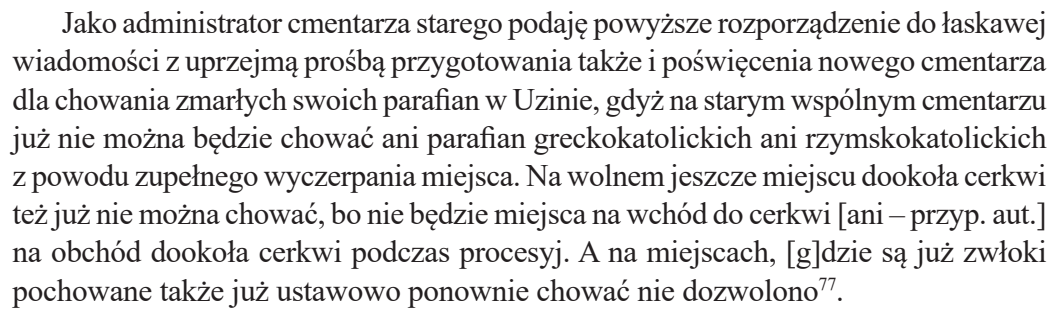

Kwestia ta była więc niezwykle pilna. Jak poświadczają kolejne dokumenty, przeor jezupolskiego konwentu, o. Klemens Kołwa OP, nie stwarzał problemów, a wręcz niezwłocznie przeznaczył jedną z działek pod nowy cmentarz. Być może kwestia ta była podnoszona już wcześniej. Zachowała się bowiem notatka, niedatowana, bez podpisu, następującej treści: „Dla pamięci! Za o. Marka darowano na cmentarz w Uzinie z parceli 611 ćwierć morga"78. Przełożeństwo o. Marka Krasa miało miejsce do 1932 r., tak więc w myśl owej notatki takie rozmowy mogły być już

${ }^{73}$ Stelmach - rzemieślnik zajmujący się wyrobem kół i innych części wozów, bryczek, sań, inaczej kołodziej. Zob.: Słownik wyrazów obcych PWN, red. J. Tokarski, Warszawa 1980, s. 701.

${ }^{74}$ APPD, sygn. Jz 18, Wykaz ubezpieczenia budowli no. 707, z dnia 28 VII 1923 r., k nlb.

${ }^{75}$ APPD, sygn. Jz 17, Dowód ubezpieczeniowy nr 1 z dnia 8 I 1937 r., k. nlb.

${ }^{76}$ Ibidem, Dowód ubezpieczeniowy nr 1 z dnia 28 XII 1938 r., k. nlb.

${ }^{77}$ APPD, sygn. Jz 17, List ks. Emiljana Kowalśhyego do przeora w Jezupolu z dnia 23 I 1937 r. $w$ sprawie cmentarza $w$ Uzinie, $\mathrm{k}$. nlb.

${ }^{78}$ Ibidem, Notatka Dla pamięci, k. nlb. 
wtedy prowadzone. Poświęcenie nowego cmentarza odbyło się 9 maja $1943 \mathrm{r}$. Konsekrował go o. Joachim Nowak. Nie wiadomo jednak, dlaczego proces przekazania parceli trwał tak długo.

Kolejną donacją z działek uzińskiego folwarku było ofiarowanie Towarzystwu Szkoły Ludowej jednej z parcel pod budowę szkoły.

Folwark w Uzinie, pracując w normalnym trybie, zarówno ponosił wydatki, jak i przynosił oszczędności klasztorowi macierzystemu w Jezupolu. I tak np. w sprawozdaniu z 1930 r. przełożony konwentu o. Marek Kras wykazał, iż folwark przyniósł 20902 zł 85 gr dochodu, a jego wydatki stanowiły 8120 zł 3 gr. Zawarł tam również informację o sprzedaży działek w latach 1919 i 1924 oraz informację, iż dochody z tych transakcji stanowiły opłatę za odbudowę kościoła i klasztoru oraz wyrównanie kontrybucji nałożonej przez prowincję ${ }^{79}$. W sprawozdaniu za lata 1928-1931 zanotował również, co obejmują wydatki z folwarku.

Wydatki folwarczne obejmują: wypłatę robocizny dziennej, kowala i stechnala, kasę chorych, oprócz tego wymianę starych koni, konserwacja inwentarza martwego kupiono nową młocarnię, zremontowano kościół, kupiono wagę decymalną, siewnik rzędowy, płużki do kartofli, parnik, kultywator. Urządzenie chlewów i kurników i remont ekonomówki również należą do wydatków folwarcznych ${ }^{80}$.

Sprawozdanie to złożone zostało za trzechlecie; wówczas folwark przyniósł klasztorowi 60565 zł 31 gr dochodu, ponosząc jednocześnie 38269 zł 30 gr wydatków.

Zdarzały się oczywiście sytuacje, kiedy folwark pozostawał zadłużony bądź miał niewyrównane rachunki z chłopami, sklepami czy prowincją. Jak wynika ze sprawozdań, starano się te zadłużenia w miarę szybko niwelować, tak aby gospodarstwo nie popadło w całkowitą stratę. Negatywną postacią na tym tle był o. Stanisław Hayto, którego krótkie przełożeństwo w Jezupolu zaciągnęło na klasztor i na folwark ogromne długi. Jego następca na urzędzie spłacał je przez kilka kolejnych lat - z sukcesem.

Wartym odnotowania są miejsca, gdzie dominikanie dokonywali zakupów pewnych towarów. Jest to możliwe w oparciu o zachowane rachunki. Rzeczy metalowe potrzebne do prac na roli kupowano w "Składzie towarów żelaznych i metalowych Karola Hauswalda” oraz w „Składzie towarów żelaznych Salomona Mendela”, a także w „Składzie towarów żelaznych Efroima Tannego". Punkty te znajdowały się w Stanisławowie. Materiały budowlane można było nabyć w „Składzie wapna, gipsu i cementu Feiwisch Kaipern” w Stanisławowie przy ul. Halickiej. W mieście powiatowym znajdowała się również fabryka maszyn R. Jaworskiego i synów, przy ul. Sobieskiego. Tam zostało zakupione koło pasowe do młocarni w $1925 \mathrm{r}$. We Lwowie działał w omawianym okresie „Związek Producentów i Hodowców Żywego Inwentarza Spółka z Ograniczoną Odpowiedzialnością", pomagający przy

\footnotetext{
${ }^{79}$ APPD, sygn. Pp 470, Status oeconomicus conventus Jezupoliensis pro anno 1930, k. nlb.

${ }^{80}$ Ibidem, Sprawozdanie za czas od 18 października1928 do 21 września 1931 z Konwentu oo. Dominikanów w Jezupolu, k. nlb.
} 
kupnie i sprzedaży bydła, rogacizny i trzody chlewnej. W Stanisławowie przy ul. Sapieżyńskiej swój zakład i sklep prowadził Józef Pieniążek, koncesjonowany majster kaflarski, z usług którego korzystali dominikanie, budując piece w budynkach folwarcznych i zabudowaniach klasztornych. Zakonnicy leczyli się ziołami, zamawiając je w „Składzie aptecznym Drogerja”, prowadzonym przez Bronisława Piętowskiego w Krakowie - Podgórzu. Na rachunku z tego zakładu widnieje również pieczątka „Laboratorium chemiczno-farmaceutyczne F. Żeliński i B. Piętowski Kraków-Podgórze”. Aby uzupełnić nasiona warzyw do wysiewu, złożono w 1929 r. zamówienie w „Hurtowym składzie i hodowli nasion szkółki drzew owocowych”, prowadzonym przez Emila Freege w Krakowie, przy ul. Lubicz 36/38. Wino mszalne do kościoła w Jezupolu oraz do kaplicy w Uzinie sprowadzano koleją z „Hurtownych składów szlachetnych win Johann Aranyi” z Krakowa. Skład ten mieścił się na ul. Mostowej 10. W sprawach spornych, zwłaszcza dotyczących sprzedaży gruntów z Uzina, klasztor jezupolski reprezentował adwokat dr Ferdynand Rydet, którego kancelaria urzędowała w Stanisławowie, przy ul. Gillera $19^{81}$. Nie są to oczywiście wszystkie punkty usługowo-zaopatrzeniowe klasztoru i jego folwarku, a jedynie te wynikające wprost ze źródeł archiwalnych.

Zaopatrzenie słusznie kojarzy się m.in. z tzw. inwentarzem martwym, czyli sprzętami i narzędziami powszechnie używanymi w kuchni oraz do pracy na polu. Zachowane spisy wymieniały sprzęty i maszyny przeznaczenia rolniczego (lokomobilę, młocarnie, sieczkarnie, wialnie do zboża, pługi, brony, siewniki, młynki, tryjery), narzędzia ręczne (łopaty, widły, kosy, sierpy, grabie, kopaczki i motyczki, drabiny, liny) oraz sprzęty kuchenne. Wymieniano wszelkiego rodzaju beczki, bańki, wiadra, cebry, skopy. Spisy inwentarza martwego pojawiały się w dokumentach dość często, również urządzenia te wymieniane są w rachunkach. Wymieniano je i uzupełniano zapewne na bieżąco, w razie zapotrzebowania czy zużycia.

Jak wspomniano wyżej, w folwarku w Uzinie stała kaplica. Zbudowano ją w latach 1894-1897 i konsekrowano w 1899 r. ku czci św. Jacka ${ }^{82}$. Służyła ona mieszkańcom miejscowości oraz pracownikom folwarku, a po zburzeniu kościoła w Jezupolu wskutek działań wojennych, od 1917 stała się na pewien czas kościołem parafialnym ${ }^{83}$. Stawiano ją również z innego, ważnego, powodu, mianowicie odległości od świątyni w Jezupolu $(9 \mathrm{~km})$. Kaplica była jednonawowa, prosta, z dostawioną kruchtą. Posiadała jedną wieżę z trzema dzwonami, na środku dachu. Prezbiterium miało kształt wieloboku. Na jego środku stał ołtarz, po lewej stronie ambona ${ }^{84}$. Niewiele więcej

${ }^{81}$ APPD, sygn. Jz 11, Administracja konwentu /i/ folwarku OO. Dominikanów w Jezupolu z lat 1833-1942, k. nlb.

${ }^{82}$ APPD, b. sygn. Catalogus fratrum ac sororum Sacri Ordinis Praedicatorum almae Provinciae S. Hyacinthi in Regno Galiciae et Lodomeriae, Magnoque Ducatu Cracoviensi Anno Domini 1904, Lwów 1903, s. 38.

${ }^{83}$ T. Zaucha, Kościót parafialny pw. Wniebowzięcia Najświętszej Panny Marii i klasztor oo. Dominikanów w Jezupolu, [w:] Kościoły i klasztory rzymskokatolickie dawnego województwa ruskiego, t. 14, red. M. Podlodowska-Reklewska, Kraków 2006, s. 105-106.

${ }^{84}$ Opis na podstawie fotografii. Zob. ibidem, il. 126-127. 
o niej wiadomo. Zachował się za to spis jej wyposażenia, pozwalający odtworzyć jej wnętrze. Sporządzony został on w 1935 r. Z uwagi na brak innych informacji o tym miejscu kultu, przytoczony został w całości. I tak w kaplicy znajdowały się:

1 ołtarz, 1 ambona, 1 konfesjonał, 2 klęczniki z kratkami do spowiedzi, 1 klęcznik $\mathrm{z}$ ławeczką, 1 fotel koszykowy, 2 ławki, 1 komoda, 1 fisharmonium, 1 baldachim, 1 feretron: obraz Matki Boskiej, 1 feretron: Dzieciątko Jezus (figurka), 1 figurka św. Józefa, 1 figurka serca P. Jezusa, 1 figurka: P. Jezus Zmartwychwstały, 1 figurka: P. Jezus w grobie, 1 krzyż procesyjny, 1 krzyż w kruchcie, 1 krzyż na ołtarzu, 2 krzyże małe do ołtarzyków, 1 obraz M. Boskiej Różańcowej w ołtarzu, 3 obrazy mniejsze na ścianach kaplicy, Droga krzyżowa (obrazki), 2 chorągwie białe, 2 chorągwie czerwone, 1 sztandar Stowarzyszenia Dzieciątka Jezus, 1 szopka z 14 figurkami, 2 tabernacula, 1 tron do wystawienia Najśw. Sakramentu, 1 umbraculum, 1 kielich z pateną z futerałem, 2 puszki, 1 monstrancja z puszką na Hostię, 1 naczynie na Wiatyk do chorego, 1 naczynie na Olej św. do Ostatniego Namaszczenia, 2 naczynia na Oleje św. do Chrztu św., 1 vasculum, 1 kociołek na wodę św., 1 kropielniczka, 1 lampka wieczna, 1 latarnia do chorego, 2 lampiony do procesji, 6 lichtarzy na ołtarz (mosiężne), 2 lichtarze trzyramienne (mosiężne) do wystawienia N. S., 2 lichtarze małe (mosiężne), 6 lichtarzy ściennych (mosiężnych), 3 lichtarze ołowiane, 3 dzwony duże (na dzwonnicy), 1 sygnaturka, 1 dzwonek na ścianie (do dawania znaku rozpoczęcia Mszy), 1 dzwonek poczwórny do dzwonienia w czasie Mszy, 1 dzwonek pojedynczy do dzwonienia w czasie Mszy, 2 ornaty białe, 2 ornaty czerwone, 1 ornat zielony, 1 ornat fioletowy, 1 ornat czarny, 3 stuły ( 2 biało-fioletowe i 1 fioletowa), 1 kapa biała, 1 kapa czarna, 3 sukienki na puszki, 3 alby, 3 humerały, 2 paski, 2 komże dla księdza, 4 komże dla ministrantów, 4 płaszcze dla ministrantów ( 2 białe i 2 czerwone), 2 obrusy lniane (pod spód), 2 obrusy płócienne (na wierzch) bez koronek, 3 konopeum białe, 3 bursy na korporał do Komunii św., 8 korporałów, 10 puryfikaterzy, 6 ręczniczków, 6 ręczniczków do vasculum, 1 bursa do chorych, 1 torebka na Oleje św., 5 koronek do obrusów ołtarza, 1 nakrycie na komodę, 1 antepedium malowane (satyna), 1 dywan ${ }^{85}$.

Wyposażenie zatem, było dość bogate, jak na małą wiejską kaplicę. Dzięki temu można w niej było przeprowadzić wszystkie uroczystości bez obaw, że którychś paramentów zabraknie. Można również postawić wniosek, iż kaplica w Uzinie była niejako oczkiem w głowie dominikanów.

Czas II wojny światowej okazał się okresem schyłkowym działalności uzińskiego folwarku. W 1942 r. o. Klemens Kołwa zwracał się do Niemców, którzy upaństwowili „cały inwentarz żywy i martwy w Uzinie”, aby z tego folwarku (lub innego) przydzielić klasztorowi z powrotem jednego konia i po dwie krowy i świnie, by wyżywić 10 osób mieszkających w konwencie w Jezupolu ${ }^{86}$. Czy prośba została spełniona - nie wiadomo. Prawdopodobnie nie, gdyż już miesiąc później wysłana została kolejna prośba przeora do władz niemieckich, tym razem o zwolnienie z przymusowego kontyngentu. Argumentacja była taka, iż klasztor w Jezupolu nie może spełnić kontyngentu, gdyż stracił źródło dochodu - folwark w Uzinie. Kontyngent ten wynosił: 2,28 m żyta z pola 35 arów, $1,50 \mathrm{~m}$ pszenicy

\footnotetext{
${ }^{85}$ APPD, sygn. Jz 17, Inwentarz kaplicy w Uzinie spisany dnia 26 lipca 1935, k. nlb.

${ }^{86}$ APPD, sygn. Jz 11, [List o. Klemensa Kołwy OP do Landsinspektora z dnia 30 VII 1942 r.], k. nlb.
} 
z pola 25 a, 20 m jęczmienia z pola 5 a, $300 \mathrm{~m}$ owsa z pola 57 a oraz 450 jaj od 10 kur i 3651 mleka od 1 krowy. Klasztor posiadał jednak wówczas tylko ogród w Jezupolu i 1 krowę, co miało wystarczyć na wyżywienie 10 osób ${ }^{87}$.

Jak zatem widać, folwark dominikański w Uzinie, zwłaszcza na przełomie XIX i XX w., pomimo burzliwych dziejów, funkcjonował całkiem nieźle. Fakt, że do zaopatrzenia miał stosunkowo niewielki klasztor w Jezupolu, w którym zazwyczaj mieszkało kilku ojców i braci. Jednakże dzięki dobrym zarządom i starannej administracji (z drobnymi wyjątkami) przez większość omawianego okresu wywiązywał się ze swoich zadań. Nawet przez kryzys gospodarczy lat 30. XX w. przeszedł w miarę bezpiecznie. Dopiero całkowita kasata konwentu, jaka dotknęła po II wojnie światowej większość klasztorów na ziemiach wschodnich, zniosła istnienie samego folwarku. Niniejszy artykuł na pewno nie wyczerpuje w pełni tematu funkcjonowania gospodarstwa dominikańskiego, jest tylko zarysem, ale dość istotnym z punktu widzenia regionalnej historii. Jak się okazuje, jest to pierwsze tego typu opracowanie dotyczące tak drobnej wioski, jaką był i jest Uzin. Należy mieć nadzieję, że nie ostatnie.

\section{Bibliografia}

\section{Źródła archiwalne:}

Archiwum Polskiej Prowincji Dominikanów w Krakowie

[b. sygn.], Catalogus fratrum ac sororum Sacri Ordinis Praedicatorum almae Provinciae S. Hyacinthi in Regno Galiciae et Lodomeriae, Magnoque Ducatu Cracoviensi Anno Domini 1904, Lwów 1903 [i inne].

[b. sygn.], Księga zmartych za okres od 1900 do 1972, oprac. E. Działa, Warszawa 1972 [mps].

[b. sygn.], Księga zmartych Braci i Ojców Polskiej Prowincji Zakonu Kaznodziejskiego czyli dominikanów od 2 lipca 1927 roku, czyli od restaurowania Polskiej Prowincji, wyd. IV, Warszawa 2007 [na prawach rękopisu].

Sygn. Js 3, Kronika Klasztoru OO. Dominikanów w Jarosławiu, 1939-1955.

Sygn. Jz 3, Kronika parafialna i klasztorna oo. Dominikanów w Jezupolu, 1600-1943.

Sygn. Jz 11, Administracja konwentu /il folwarku OO. Dominikanów w Jezupolu z lat 1833-1942.

Sygn. Jz 17, Akta administracji majątku Uzin z lat 1825-1943.

Sygn. Jz 18, Akta gospodarki leśnej w Uzinie, 1896-1942.

Sygn. Kn 73, Kartoteka biograficzna dominikanów polskich.

Sygn. Pp 470, [Akta dotyczące spraw klasztoru dominikanów w Jezupolu]

\section{Opracowania:}

S. Barącz, Rys dziejów zakonu kaznodziejskiego w Polsce, Lwów 1861.

A. Bołdyrew, Źródła do badań nad ochronkami jako instytucjami opiekuńczo-wychowawczymi w Królestwie Polskim w XIX i na początku XX wieku, „Studia Paedagogica Ignatiana”, vol. 19, 2006/2, s. 271--289.

A. Czułowski [Czołowski], Z przeszłości Jezupola i okolicy, Lwów 1890.

S. Czyżowicz, M. Czarnecki, Krotoszyn koło Lwowa, Namysłów 2014.

W. Hinnebusch, Dominikanie - krótki zarys dziejów, [w:] Dominikanie. Szkice z dziejów zakonu, red. M. Babraj, Poznań 1986, s. 83-267.

${ }^{87}$ APPD, sygn. Jz 11, Prośba klasztoru oo. Dominikanów w Jezupolu o zwolnienie od kontingentu, 10 VIII $1942 r$., k. nlb. 
Jezupol, [w:] Słownik geograficzny Królestwa Polskiego i innych krajów słowiańskich, wydany pod redakcją Filipa Sulimierskiego, Bronisława Chlebowskiego i Władysława Walewskiego, t. 3, Warszawa 1888, wyd. reprint, Warszawa 1986, s. 581.

D. Kadzik, Obrona ziem ruskich przed najazdami tatarskimi w latach 1575-1578, „Zeszyty Naukowe Uniwersytetu Jagiellońskiego. Prace Historyczne", 143, z. 2 (2016), s. 269-276).

P. Krasny, Kościót parafialny p.w. św. Mikołaja i św. Zofii oraz klasztor oo. dominikanów w Tyśmienicy, [w:] Kościoły i klasztory rzymskokatolickie dawnego województwa ruskiego, t. 14, red. M. Podlodowska-Reklewska, Kraków 2006, s. 449-462.

A. Lipski, Potocki Jakub h. Pilawa, [w:] Polski Stownik Biograficzny, t. 28, red. E. Rostforowski, Wrocław-Warszawa-Kraków 1984-1984, s. 18-21.

R. Majewski, Z problematyki walk z Tatarami w pierwszej połowie XVII wieku, „Sobótka”, 2 (1975), s. 231-241).

M. Miławicki, Kształtowanie się własności ziemskiej klasztoru dominikanów w Krakowie w okresie przedrozbiorowym, [w:] Inter oeconomiam coelestem et terrenam. Mendykanci a zagadnienia ekonomiczne, red. W. Długokęcki, T. Gałuszka, R. Kubicki, A. Zajchowska, Kraków 2011, s. 277-302.

M. Miławicki, Prowincjałowie dominikańskiej Prowincji Galicji i Lodomerii św. Jacka. Prolegomena do badań prozopograficznych, [w:] Historia, ludzie i miejsca. Ksiega pamiatkowa profesora Henryka Gapskiego, red. R. Kozyrski, Lublin 2019, s. 485-516.

M. Miławicki, Zaplecze gospodarcze klasztorów dominikańskich $w$ diecezji kamienieckiej w świetle akt wizytacji z $1823 \mathrm{r}$., [w:] Dominikanie na ziemiach polskich w epoce nowożytnej, red. A. Markiewicz, M. Miławicki, Kraków 2009, s. 485-517.

M. Miławicki, Źródła do poznania zaplecza gospodarczego dominikańskiego klasztoru Bożego Ciała we Lwowie w latach 1918-1939, [w:] Історія релігій в Україні. Науковий щзорічник, Львів 2006, s. 396-407.

W. Roszkowski, Najnowsza historia Polski 1914-1945, Warszawa 2003.

Stownik języka polskiego, t. 1: A-K, red. M. Szymczak, Warszawa 1978.

Stownik wyrazów obcych PWN, red. J. Tokarski, Warszawa 1980.

J. Szymański, Nauki pomocnicze historii, Warszawa 2012.

T. Trajdos, U zarania karmelitów w Polsce, Warszawa 1993.

T. Trajdos, Uposażenie klasztoru dominikanów lwowskich w średniowieczu, „Nasza Przeszłość”, 91 (1999), s. 47-76.

L. Ulanowski, Wiadomość historyczna o obrazie Matki Boskiej OO. Dominikanów we Lwowie, Lwów 1851.

Uzin, [w:] Stownik geograficzny Królestwa Polskiego i innych krajów słowiańskich, wydany pod redakcja Filipa Sulimierskiego, Bronisława Chlebowskiego i Władysława Walewskiego, t. 12, Warszawa 1892, wyd. reprint, Warszawa 1987, s. 808.

Ł. Wenc, Fundacje i fundatorzy klasztorów dominikańskich i bernardyńskich $w$ Polsce $w$ latach 1580-1648, [w:] Studia nad historia dominikanów w Polsce 1222-1972, red. J. Kłoczowski, t. I, Warszawa 1975, s. 587-606.

G. Wierzchowski, Inwentarz folwarku Piaski z 1755 r. Przyczynek do dziejów gospodarczych sieradzkich dominikanów w XVIII w., [w:] Dominikanie na ziemiach polskich w epoce nowożytnej, red. A. Markiewicz, M. Miławicki, Kraków 2009, s. 469-484.

T. Zaucha, Kościót parafialny pw. Wniebowzięcia Najświętszej Panny Marii i klasztor oo. Dominikanów w Jezupolu, [w:] Kościoły i klasztory rzymskokatolickie dawnego województwa ruskiego, t. 14, red. M. Podlodowska-Reklewska, Kraków 2006, s. 97-120.

M. Zdanek, Dochody dominikanów krakowskich w 1 pot. XVI w., [w:] Inter oeconomiam coelestem et terrenam. Mendykanci a zagadnienia ekonomiczne, red. W. Długokęcki, T. Gałuszka, R. Kubicki, A. Zajchowska, Kraków 2011, s. 259-276.

\section{Strony internetowe:}

https://sjp.pwn.pl/doroszewski/gumienny;5432153.html [pobrano: 29 III 2021 r.]. 